\title{
Between Racialization and White Supremacy: Another Marxist Response to Sean Walton
}

\author{
Ayodeji Bayo Ogunrotifa \\ Department of Law and Criminology, Royal Holloway, University of London|RHUL, London, UK \\ Email: ayodeji.ogunrotifa.2008@live.rhul.ac.uk
}

How to cite this paper: Ogunrotifa, A. B. (2022). Between Racialization and White Supremacy: Another Marxist Response to Sean Walton. Open Journal of Social Sciences, 10, 240-257.

https://doi.org/10.4236/jss.2022.102017

Received: January 7, 2022

Accepted: February 20, 2022

Published: February 23, 2022

Copyright (อ 2022 by author(s) and Scientific Research Publishing Inc. This work is licensed under the Creative Commons Attribution International License (CC BY 4.0).

http://creativecommons.org/licenses/by/4.0/ (c) (i) Open Access

\begin{abstract}
Following the debate between Marxists and the Critical Race Theorists (CRT) over the analytical utility of the concept of White supremacy in the contemporary discourse on racism, this paper offers an additional Marxist response to Sean Walton's article to complement the existing Marxist thoughts on the debate. This paper further deepens the discussion on racialization as the general descriptor of racism in western societies, by introducing the class context in which racialisation has sustained and maintained racism in the contemporary era. Racialization is defined in this paper as an ideological process that involves racialising benefits, privileges, and opportunities to one group [possibly an ethnic group] over other groups by the capitalist ruling class and the state, and legitimising it by using policies, media, laws, regulations, and institutional practices as a means of entrenching division and disunity in the society and preserving their system of control under capitalism. Following this definition, it is argued that racism is being reproduced through the process of racialization in the contemporary western society. In the overall discussion on racialisation and White supremacy, the ideology of racism was espoused, and the future of racism as articulated in Critical Race theory and Black radicalism is reviewed.
\end{abstract}

\section{Keywords}

White Supremacy, Racialisation, Black Radicalism, Racism, Marxism

\section{Introduction}

The articulations of the concepts of White Supremacy and racialization have generated a wide array of commentaries, critiques and debates between Critical Race Theorists (CRTs) and Marxists about the analytical utility of both frameworks in explaining and understanding racism in contemporary western society 
(Mills, 2009; Cole, 2009a; 2009b; 2009c; 2016; 2020; Walton, 2020). This article responds to Sean Walton's argument, published in the journal of Power and Education, that the Marxists should not dismiss the Critical Race Theory (CRT) concept of White Supremacy. I welcome Sean Walton's contribution that appealed to incorporating the CRT concept of White Supremacy into the Marxist lexicon, framed in terms of the reading and traditions of Black radicalism. In doing so, Walton brings to the fore the crucial contributions of Black radical theorists on the impact of western imperialism, whiteness, and the claim of the subordination of the struggle of Black workers into the emancipatory discourse of the White working class, as a way of strengthening the analytical utility of White Supremacy.

Walton is undoubtedly correct to articulate this valuable work but the enclosing and understanding of White Supremacy, together with its connection to Black radicalism, by my reckoning, are problematic for some reasons that Cole (2009a; 2009b; 2009c; 2020) had not highlighted. In the discussion of racism, Cole (2020) questioned the fluidity of whiteness, which is the basis of White Supremacy in the paper, and argued that such articulation is not relevant to Jewish people, Eastern Europeans and Irish people, who possess "White skin" and have experienced racism either in historic period or in contemporary era. Cole further questioned the analysis of racism around Black/White binary in the CRT, and insisted that if White supremacy is no longer directed at these aforementioned groups, then neo-Marxism is not needed in explaining the fluidity of Whiteness that underpins White supremacy. Cole's robust response is particularly salient in challenging and deconstructing the notion of White Supremacy and reaffirming the intellectual sanctity of racialization in the discursive exposition of racism and deepening debate around the nexus between the two concepts.

However, what seems limited in Cole's articulation revolves around three key issues. The first is the inability to concretely demonstrate how the unity of all people (oppressed 99 percent) irrespective of their race, religion, ethnicity, gender and sexuality is fundamental to the emancipatory project of Marxism, which contrasts with the race discourse that underpins the concept of White Supremacy. The second is the lack of analysis on how racism as an ideology is integral to institutional racism that shapes discussion around biological categories of intelligence/differences in I.Q. and academic attainment between White and Black people, a fundamental premise on which Walton's argument about White Supremacy rests. The third point is the inability to critically scrutinize the claims of Black radicalism and expose how the theoretical blind alley around the framework is inhibiting and constituting an impediment to future discussion on the anti-racism movement or the eradication of all vestiges of racism in western society.

This lacuna is what I seek to articulate briefly in my response to Sean Walton below. My reply is not intended to challenge Cole's work but to expand it. Finally, this response critiques the CRT concept of White Supremacy and deepens the Marxist analysis and understanding of racism in contemporary western society. I 
begin by reviewing the rationale for Marxists' opposition to the White Supremacy concept.

\section{Why Marxists Oppose the White Supremacy Concept}

Mike Cole has provided a Marxist explanation that challenges the claims of CRT on White Supremacy for more than ten years. Cole's critique of White Supremacy was not undertaken to oppose proponents of the CRT but to lay a significant hypothetical base that could help in the campaign against racism in practice. My engagement here is not to simply rehash Cole's positions but to make further additions and deepen them by referring to concrete situations and realities. In instances where most of Cole's positions are not stated, it is because I share those positions. Therefore, the reasons for Marxists' opposition to the White Supremacy concept can be limited to the three points below.

First, the ontological question of race that underpins White Supremacy is fundamentally different from the Marxist ontological question of class that underlines the analysis of racism in western society. Thus, the class question, which emphasizes the primacy of class over race, differentiates Marxist ontology from the CRT concerning White Supremacy and other broad forms of racism.

In CRT parlance, White Supremacy is a manifest representation or form of racism in which White people are the culprit. To Marxists, "What is racism?" is an ontological question that is socially constructed in socio-cultural life, and it is used as a tool or strategy by the capitalist ruling class to divide the society along with the colour or racial line and prevent the unity of the people to protect and sustain the capitalist system (Cox, 1959). The central question of race inherent in the discourse of White Supremacy as a form of racism cannot explain class issues due to the narrow remit of its existence. It is my position here that the proponents of CRT reduce the analysis of White Supremacy to race discourse, and the implication of this is that the CRT falls into the sectarian prey of racism that it seeks to deconstruct, eradicate and reject. Race is, therefore, less broad and less encompassing in analyzing racism than class. Through this ontological question, it is the Marxist position that racism cannot be reduced to social class, but the analysis of racism cannot be entirely undertaken and understood without class analysis. To extend this dialogue to the concept of White Supremacy, the primacy of race alone is more limited and narrow in explaining racism than it is with class.

Second, the principal objective of Marxism is to deconstruct capitalism, establish a classless society and eradicate all forms of prejudices, including racism, in the society. This objective fundamentally contrasts with the idea of CRT, which believed that racism could be resolved under the framework of capitalism, where White Supremacy could be deconstructed. In Marxist parlance, racism cannot be resolved within the capitalism framework because racism is sustained by the class structure of the capitalist system. The eradication of class society would lead to equality between classes and between ethnic groups. 
Under capitalism, men and women are oppressed as part of the working people by the ruling class, and such oppression is sustained by the class structure of the capitalist society (Glassman, 2006; Hill, 2020). If there is class oppression of the White working-class by the White capitalist class, then there is no guarantee that there would not be class oppression of Black workers by White bosses or Black bosses. Racism is sustained by the class structure of the capitalist system and the structure of control and power of the White ruling class that accompanies and reinforces it. In CRT, eliminating White Supremacy connotes eliminating racism. The remit of Marxism is beyond racism, as it involves abolishing other forms of prejudices like Sexism, Islamophobia, Homophobia, among others, and this involves the deconstruction of capitalism and the structure of the class, power and oppression controlling it, and establishing a classless society. The dissolution of the culture of classes (class society) would remove inequality, oppression and injustice because there would be no class to sustain the system of inequality, oppression and injustice under socialism. Consequently, Marxists reject the concept of White Supremacy because the primary interest of CRT is to solely deconstruct and abolish racism, while that of Marxists is to deconstruct a capitalist system that sustains the culture and system of prejudices in society, including racism.

Third, the concept of White Supremacy inhibits the emancipatory project of Marxism, which prioritizes the unity of all oppressed people based on gender, race, class, ethnicity, religion, and sexuality. That was why Marx and Engel canvassed that the workers of the world should unite (Marx \& Engel, 2014). Unity is central to the Marxist emancipatory project, and it requires conscientization and making people conscious of the condition of their existence under capitalism. Its success depends on uniting them collectively along the class line to challenge and deconstruct the capitalist system responsible for their experience of oppression, discrimination, and other forms of prejudice. The unity of all oppressed people that Marxists advocate and pursue is anathema to the narrow interests of Black and other ethnic minorities that White Supremacy advocates in CRT prioritize. The divisive nature that the concept of White Supremacy generates would make Marxists reject it.

Finally, Marxists oppose the White Supremacy concept because of the homogeneity of all White people, as Cole argued (Cole, 2016; 2020). The concept is misleading due to the vagueness associated with its expression, especially with reference to the sweeping categorization of White people as a single or homogenous group. Who are the White people to whom the CRT advocates refer? Are CRT advocates referring to White people of the White ruling class, White middle class, White working class, or White underclass? This class classification has demonstrated that White people are not homogenous, as they are divided by their class positions and interests regarding the power structure and capitalist system in western society. For instance, most U.K. towns are replete with substantive numbers of primarily White homeless people. Is the concept of White Supremacy applicable to these White homeless people too? The homeless White 
people and destitute, in my reckoning, are part of the White underclass, who are also the victims of the capitalist system like the Black underclass and Black working class.

Even if the CRT argument about White Supremacy is valid, the question would be: Who are the White people who expressed White Supremacy? This question is the fundamental issue inherent in the conceptual frame of White Supremacy. If the answer to this question is not likely to be the homeless and other White underclasses, then the answer would likely be the White ruling elite/class. It, however, brings us back to the superiority of class issues over race questions in the understanding of racism. In Marxism, the White working class (college-educated or not) are also the victims of the capitalist system, just like the Black working class. Therefore, the closest ally of Blacks and other ethnic minorities in the fight against racism would naturally be the White working class and perhaps, some sections of the White middle class. The unity of these classes, which Marxism preaches, is central to the fight against all forms of racism. Therefore, the notion of White Supremacy, as Cole (2009c) argues, is totally counter-productive and does not unify people of different ethnic persuasions politically because the White working class and some sections of the White middle class will not want to work, solidarize and collaborate with the working class and middle class from Blacks and other minorities communities, who always consider them as White supremacists. It undermines the unity of all classes and people's unity, reinforces division, and entrenches racism rather than challenges it.

\section{Racism as an Ideology}

One of the fundamental gaps in Walton's work is the failure to consider the ideology of racism as central to the discussion of institutional racism inherent in the biological categorization of differences in I.Q. and academic attainment between White people and Black people in education, in which his analysis of White Supremacy was premised. Walton's argument relied on Gillborn's (2016: p. 86) observation on the persistent pseudo-scientific ideas in the education sector, policy and practices. Gillborn perceived "that Black pupils are genetically less academically able than White pupils who are disproportionally influential with educational policymakers in the U.K. and that scientists peddling these ideas are given far too much credence by White politicians, particularly those operating in the educational sphere" (Walton, 2020: p. 86). Walton contends that Gillborn's observation did not appeal to a mode of production in articulating the racialization processes based on biological racial categories. Nevertheless, it still addressed racialization in another dimension. Hence, "racialization is, in part, a consequence of White supremacy and not a concept that can replace it" (Walton, 2020: p. 87).

It is essential to state here that the ideology behind Gillborn's observation is based on race discourse, not class question, and therefore, Gillborn's attempted racialization of biological racial categories is intended to reinforce the race discourse that is limited and narrow. As Walton claimed, based on this premise, ra- 
cialization is not a consequence of White Supremacy but its replacement. The limitation in both Gillborn's and Walton's positions is the failure to consider racism as an ideology in their discussion of White Supremacy, and it is an important area which this paper will address now.

The fundamental proposition in the Marxist analysis is that racism is an ideology that is characterized by its content, which "asserts that or assumes the existence of separate and discrete races and attributes a negative evaluation of one or some of these putative races" (Miles \& Brown, 2003: p. 84). The question of who makes and utilizes this content as ideology or who ideologized this content is a glaring omission in Miles and Brown's articulation.

As a form of discrimination and prejudice that people experience based on their membership of a particular ethnic group, racism is a social construct (in its own right) and existed prior to the advent of capitalism (Trachtenberg, 1943; Biller, 1992; Strickland, 2003; Patton, 2015). The form of racism in the feudal era was based on cultural classification (Stoler, 1997) rather than biological categorization (Miles \& Brown, 2003), and this cultural classification of “Other" includes Arabs, Chinese, Indians, and Muslims based on signification (European representations of "Other"). Following this cultural classification, racism was prevalent and manifested in forms of anti-Irish prejudice, anti-Semitism and anti-Muslims or where "borderline Europeans" like the Irish, Slavs, Roma, Mediterraneans, Gypsy, the Muslim communities or those perceived to be Muslim and Jews (Mills, 1997; Tolan, 2002; Heng, 2003, 2018; Bale, 2006; Ziegler, 2009; Akbari, 2009) were regarded as backward, inferior and barbaric.

Advancements in science and technology accompanied the advent of capitalism in western Europe. The scientific classification of people into distinct races with specific biological characteristics laid the basis for the ideological foundation of racism in the capitalist era (Banton, 1991; Miles, 1989; 1993; Webster, 1993). The European ruling class hijacked and exploited the biological compartmentalization of races as an ideology to justify the enslavement of Africans and the attendant genocide, conquest and war that followed the colonialization and imperialism of native people in Africa, Asia, America, and Australasia as "inferior races". In other words, race as a "scientific" fact was transformed into an ideological category and tool by the ruling class and the state to justify Black slavery in the southern states of America, the Jim Crow Law and segregations, and Jewish pogrom and genocide in Nazis Germany. Racism existed prior to race discourse ${ }^{1}$, and the ideology of racism, which the European ruling class utilized, was derived from the race discourse.

Following the pogrom and genocide of Jewish people (as inferior race and

${ }^{1}$ The race discourse is derived from the general race theory of the $18^{\text {th }}$ and $19^{\text {th }}$ century by biologists and scientists, who categorised people into distinct "races" based on anatomical or phenotypical characteristics. With racial theory, in individuals are racially classified based on anatomy and phenotype, and these biological characteristics are presented as the explanation for their social behaviour, cultural orientations and historical development (Banton, 1991). The logic of race discourse depicts that once an individual is racially classified, their genetic attributes are invoked to explain their social behaviour. 
alien) by Hitler and the Nazis regime in Germany, UNESCO inaugurated a panel of scientists to evaluate the scientific evidence on race and racism (Miles \& Brown, 2003). The UNESCO Panel dismissed the nexus between race and racism and posited that:

"Racism falsely claims that there is a scientific basis for arranging groups hierarchically in terms of physiological and cultural characteristics that are immutable and innate.” (Montagu, 1972, cited in Miles \& Brown, 2003: p. 60)

The conclusion of the UNESCO Panel laid the foundation for the discrediting and deconstruction of "race" as an analytical framework in social science discourses. Despite being discredited as an analytical construct, the race discourse is still being used by the western ruling class as an ideological trump card in covert fashions, purposely for the sustenance of the capitalist system. Therefore, racism is an ideology of the western ruling class founded on race discourse, initiated through state and social institutions to foster division and disunity in society, to protect capitalism from being challenged by workers of different ethnicities along the class line.

Indeed, until today, the western ruling class is still using the scientific theory of race in their ideology of racism to racialize sections of the population for their capitalistic ends in western society. With racism as their ideology, the ruling class invests heavily in race discourse as Webster (1993: p. 27) observed:

The racial theory for contemporary social studies is supported by foundations and corporations, which invest comparatively vast sum of money in research on the experiences of racial and ethnic groups. Given this financial backing, social scientists are able to ply government, media and citizens with an abundance of a racial data.

The investment of the ruling class in racism is to further entrench and institutionalize the race discourse as a way of legitimating exclusionary practices, prevent the BAME groups from realizing that they are being racialized, and create a division in society along the racial line as a means of protecting capitalism from being challenged and so protecting their class interests. The underlying thrust of the race discourse, as Webster (1993) argued, is the preservation of the racial classification of persons, experiences, and social phenomena. The purpose of investment in racism by the ruling class is to ensure that racialized Blacks and other ethnic minorities perpetually remain in the state of what Miles and Brown (2003: p. 6) regarded as "race consciousness". Here, poverty experienced by Inner City Blacks in London or Chicago could be attributed to their race rather than the capitalist system, which requires poverty at one end to maintain the system. By prioritizing the race discourse, CRT proponents are supporting the narratives of the ruling class that race is responsible for the poverty, institutional inequality, and marginalization experienced by the Black and ethnic minorities.

Racism, as derived from the race discourse, is a tool used by the capitalist ruling class to preserve the status quo covertly. In the contemporary practice of 
racism, explicit reference to biological inferiority and superiority by the ruling class have been rare, but the policy, laws, and regulations enacted have been overtly and covertly racist because it is based on the idea of race to legitimate exclusionary practices and racialization against sections of the population. For instance, the analysis of the austerity budget implemented by the Conservative government from 2010 has revealed that the cumulative effect of tax and benefit changes since 2010 has made BAME women worse hit and made the poorest Black and Asian women some $£ 2000$ worse off, while the wealthiest people were slightly better off (Women's Budget Group, 2016; Khan \& Shaheen, 2017). The budget presented by the then U.K. Chancellor (George Osborne) did not refer to race or the BAME groups. A policy, law and regulation do not need to refer to a biological theory of inferiority and superiority to be a racist policy, and anyone who is hoping to see a policy, law and regulation as a reference to race would never see one as far as contemporary public policy is concerned.

The Conservative austerity was implemented to rescue British capitalism from its organic crisis following the global financial crisis of 2009-2010. Nonetheless, if we analyze the political and ideological context of such policy like the Conservative austerity budget, racialized representation of certain sections of the population is widely reproduced. The modern expressivity of racism and exclusionary practices are covert, hidden, and disguised, as the mechanism of exclusion and racialization are concealed in any policy, law and regulation. In contrast, the political and ideological context of such policy and law are racist in their articulation.

Miles' corpus of work on racism (Miles 1982; 1989; 1993) was closer to this assertion. What differentiates Miles' argument from mine is that Miles considered the state (British state) the agent of racialization, while I consider the British ruling class the culprit of racialization here. The ruling class's ideology shapes the fundamental objectives of state policy in western society, and in most instances, it is the ideology of the ruling class that translates into state or public policy. My argument here is that racism is the ideology of the western ruling class, and racialization is the method through which such racist ideology is reproduced. The observation of Carter et al. (1987: p. 335) succinctly captures this reality:

"The problem of colonial migration has not yet aroused public anxiety ... [But] if immigration from the colonies, and, for that matter from India and Pakistan, were allowed to continue unchecked, there is a real danger that over the years there would be a significant change in the racial character of the English people."

The above commentary formed the Minute of the Cabinet Meeting held on the $3^{\text {rd }}$ November 1955 , which Carter and his colleagues cited verbatim. This commentary revealed that playing the race or racial game is rooted in the ideology of the British ruling class, and by extension, the western ruling class. It was this ideology of racism that led to the passing of the 1962 Commonwealth Im- 
migration Act. The Act ended "the automatic right of people of the British Commonwealth and colonies to settle in the United Kingdom who were overwhelmingly Blacks and Asians' (McKay, 2008). Critics of the Act had argued that 'the legislation was racist in intent because some of those responsible wished to maintain the racial homogeneity of the existing population"' (Banton, 2005: p. 63). Recent evidence by Micheal Banton revealed that a Conservative Minister at the time (William Deedee) acknowledged that the "real purpose of the Act was to restrict the influx of coloured Immigrants" (Banton, 2005: p. 65). This expression of a Conservative Minister shows the concern of the British ruling class and the state institutions about the racialization of immigrants. Therefore, the 1962 Commonwealth Immigration Act was passed by a Conservative government (a pro-business party and a section of the British ruling class) to racialize Black and Asian immigrants as the problem, using law, policy and regulation to protect the British racial character of whiteness (Rattansi, 2005).

The race discourse that underpins racism ideology is the weapon that the western ruling class utilizes in all institutions of western society to divide the people along the ethnic line. It maintains its hold on society by racializing one ethnic group against another to prevent class unity, using the media (owned and controlled by the ruling class), state policies, laws and regulations, and institutional practices. The consequences of this have been a colossal gap or considerable differences between the Whites and the minority ethnic groups, in a whole range of areas such as housing, employment, occupation, education, health and social deprivation (Cohen, 2001; Li \& Heath, 2008; Li, 2017).

Cole and Maisuria's observation (2010: pp. 108-109) is particularly salient in providing the evidential basis of this assertion:

"Hence the use of capital is to open the markets, and the role of sections of the tabloid media is to racialize migrant workers to keep the (white) working class happy with their lot with the mindset that 'at least we are not Polish or Asian or black, and we've got our flag and, despite everything, our brave boys in Iraq did us proud'." (Cole \& Maisuria, 2010: pp. 108-109)

The critical insight in Cole and Maisuria's work is the use of media to racialize one section of the working class against another on ethnic or racial lines. Aside from the media, the ruling class utilizes racialization to legitimate the allocation of benefits, advantages, and privileges to the White population against Black and other ethnic minorities. It gives White people the mindset that they are better than Blacks and other ethnic minorities, and thus, creates unequal relations that could prevent unity and solidarity across ethnic groups on class lines, which could pose a threat to the future of capitalism as a system and the position of the ruling class as a class. Therefore, racialization is the ideological process through which the ideology of racism is perpetuated and sustained by the ruling class in society by racializing one group against others to sustain capitalism.

In addition to Miles and Cole's works on the mode of production framework, this class analysis of racialization could be further developed in future research. 
Returning to Walton's argument, relying on Gillborn's observation (Gillborn 2018 ; 2019) is problematic. Here, racism is being re-racialized through biological categories of intelligence levels of different racially identified groups to account for differences in I.Q. and academic attainment between White and Black people, as a case justifying that White Supremacy exists without a mode of production. The persistent quest to rehash the discredited biological and genetic factors in educational attainment manifests racism as an ideology in which racialization is drawn. Walton fails to grasp how racialization that emerges from Gillborn's work (as institutional racism in education and biological categorization of intelligence level) is the reproduction of racism as an ideology in institutional practices and procedures.

Gillborn's observation is an evidential expressivity of racism as an ideology in education, manifesting as institutional racism. Rattansi (2005: p. 289) regarded it as "institutional racialization", borne out of the racialization process that the capitalist ruling class has instilled in society's social and cultural institutions. The reproduction of racism in everyday life against the racialized Other is activated by the conjuncture of social relationships that have been "poisoned" by the racist ideology that the ruling class has instituted in the society over decades, which has filtered through every facet of state and social institutions like education in western society.

Despite this scientific idea being discredited as flawed, the ruling class and its representatives are still racializing this claim to distract the public's attention from the problem of attainment gap and falling standard of public schools, that stemmed from the austerity cut in education budget under their watch (Simpson et al. 2017; Shain, 2016). Also, it seeks to avoid public scrutiny not only on the lack of state funding for public schools but the effects of an austerity-led cut in social spending, especially on primary and further education. Hence, Gillborn's study on which Walton based his White Supremacy analysis is the expression of racism as an ideology in educational or institutional practices and procedures.

\section{Black Radicalism}

Walton's argument that Marxism is developed based on western experience is similar to the positions of Robinson (1983), Mills (2003), Andrews (2016, 2018) and the arguments of other Black scholars in CRT and Black radical traditions, which over the years, had argued that Marxism should be tweaked to accommodate the experience of Black people and Black workers. I believe that these black scholars' standpoints are flawed and disingenuous because the real test of a theory is revealed in its application. A theory always develops from a particular context, but its relevance lies in its applications to other contexts and experiences. The call to tweak Marxism to accommodate Black experience is rather unfounded, as historical materialism, class analysis, mode of production, and other theoretical variants in Marxism are sufficient in capturing the experience of Black people and Black workers throughout history. For instance, Walter 
Rodney, in his modest utilization of historical materialism in How Europe Underdeveloped Africa, observed that Africa and Africans were at the feudal stage when colonialism, slavery and western imperialism ensued (Rodney, 1972). In other words, Africans or Black people were at the stage of feudalism during European colonization and transatlantic slavery. The proponents of Black radicalism could have taken this position further, but due to the theoretical blind alley of race, construed as an analytical framework that underpinned their studies, they could not undertake this engagement.

The attempt by Robinson (1983) to integrate Black radicalism and Marxism was problematic because of the contrasting theoretical paradigms and the incompatibility of ideological leaning that underpinned both traditions. Thus far, the articulations of Black scholars in the CRT and Black radical tradition has been the churning out of concepts like White Marxism, racial capitalism, racialized capitalism, racist state, intersectionality, and racist capitalist media that are enabling racism rather than challenging it. Therefore, a Black radical position that White workers are in a "relatively priviledge position in comparison to their Black and non-White counterparts" (Walton, 2020: p. 88) is a manifestation of the racialization politics used by the ruling class to give White workers advantages to keep them apart from the other racial groupings and to prevent challenges to their class status during the period and crisis of capitalism.

Second, the argument of Andrews (2018) reiterated by Walton (2020: p. 87) that Marxists have ignored or downplayed "the impact of Western imperialism in defining the different relationships to capitalism in which White workers and their Black counterparts stand" is unfounded. As Walton claimed, in Marxist parlance, imperialism is the later stage of capitalism, not the relationship to capitalism. With capitalism, both Black and White workers are exploited and oppressed by capital rule and the capitalist ruling class. The primary interest of Marxism is to unite both groups of workers to challenge and overthrow capitalism. Furthermore, Andrews's (2018: p. 87) stance that the Marxist movement tends to be complicit "in the differences in the distribution of the benefits of capitalism across racial groups, and thus makes it difficult for non-white groups to identify with the struggles of the White working class" is an attempt to divide the working class who are part of the 99 per cent that are victims of the capitalist system along the ethnic line. Analyzing how the ideology of racism has been central in apportioning and distributing the benefits of capitalism to one ethnic group over another by the ruling class is the starting point to build trust and forge unity within the working-class movement.

In contrast to the race discourse implicit in Andrews' critique, uniting the working class in Marxist parlance would always be on the class line, where it would be demonstrated that these advantages, benefits and privileges that were apportioned to White people do not stem from the benevolence and generosity of the British ruling class. Instead, these benefits and privileges were apportioned to White people, and are used to create an artificial division and halt class unity 
irrespective of ethnicity, thereby making It difficult to challenge the ruling class and the capitalist system under their control.

Second, the notion of psychosis of whiteness (Andrews, 2016), which Walton claimed that Marxists have ignored, is counter-productive to the anti-racist struggle and movement that requires the unity of all classes and ethnic groups, as Marxism advocates, in defeating racism and the capitalist system that sustain it. The psychosis of whiteness could be misunderstood by the White working and middle class as abusive, insulting, and discriminatory. Thus, Andrews' argument about the psychosis of whiteness is a divisive notion, capable of reinforcing and contributing to entrenching the White ruling class to permanently ensure the segregation between White, Black and other ethnic minorities in society.

In discussing the future via the Black radical perspective, Andrews (2018: p. 84) offered a solution; to overthrow the western empire. It is not clear what is meant by "western empire". Is Andrews referring to western capitalism and imperialism? Nevertheless, capitalism and its later stage, imperialism, started as an empire-building process that led to expanding the western sphere of influence beyond the European shores to other parts of the world. I agree with Andrews that the overthrow of western imperialism would lead to the eradication of racism. However, the fundamental question of how this could be achieved is what Andrews later proposed.

The first is the creation of a movement of the masses (Andrews, 2018: p. 92), and this movement must never be national but rather global, since racism:

"transcends nation state boundaries [given that] ... African diasporas separated by thousands of miles are similar than those experienced by their allies of 'colour' in the adjacent neighbourhood." (Andrews, 2018: p. 81)

The end goal of this movement is to achieve a Black revolution, which "is based on the idea of creating a world entirely independent of the oppression of the West" (Andrews, 2018: p. 251). I agree with the idea of a global movement against western imperialism because imperialism is global, and the method to overthrow it must be global. However, this proposal obscures two crucial realities. First, racism is not the only reason imperialism has to be overthrown. It is not only racism that we want to end, but we also want to end global hunger, poverty, malnutrition, genocide, war, climate change and other problems caused by capitalism and imperialism across the world. Second, imperialism is the later stage of capitalism, as Lenin demonstrated a few decades ago. Imperialism rests on capitalism across different nation-states, with different local bourgeoisie (capitalist ruling class) as the appendages of global capitalism and imperialism. The capitalism and the capitalist ruling class in developing countries are the springboards in which global capitalism, and by extension, global imperialism, festers. Therefore, without overthrowing capitalism and smashing the local bourgeoisie in different nation-states, Andrews's proposal to overthrow imperialism seems illusory and unrealistic. 
The second solution is the establishment of a global Black nation (Andrews, 2016: p. 94) rooted in Marcus Garvey's ideal of Black independence, which Andrews noted as "the basis of black radicalism: aiming not just at being apart from the West but being immune to its poisonous influence by being completely independent from it" (Andrews, 2016: p. 250). A global Black nation is unrealistic because there are presently fifty-four African countries and subsuming these countries into a single monolithic is awkward. Furthermore, as proposed by Andrews, the strategies of Black independence and Black revolution that revolve around a global Black nation cannot be achieved without a class struggle against the local bourgeoisie, the adjuncts of western imperialism. In reality, Black independence would not stop the western "poisonous" influence of capitalism and imperialism from penetrating the "new Black nation" if it existed.

Also, the idea of Black independence in Andrew's proposal is founded on the blueprint of capitalism, the same system that sustains and supports racism that Black radicalism seeks to eradicate. My viewpoint here is that Black independence cannot be achieved without overthrowing capitalism and establishing socialism, where the people run society.

Indeed, Black independence cannot be achieved without connecting the everyday struggle of Black people to that of other oppressed people around the world. For instance, there was no justification for the refusal to link and connect the struggle of the South African farmers (who were on strike over pay and working conditions) with that of the potential British teachers' strike over pension changes at a Black History Month event attended by Andrews and some members of the Black community in Birmingham in 2012 (Andrews, 2016: pp. 179-181). The rejection of solidarity, collaboration, and support of the Socialist Workers Party on behalf of the teachers from the Black community (acting on behalf of the striking South African farmers) is because the teachers' race was White, not because both groups are working class and victims of capitalist policies of their respective states/governments. The implication of this scenario is the entrenchment of division and fostering of disunity of people to collectively confront the common enemy of capitalism that prolongs racism and causes other social problems affecting the workers and the people. Therefore, Black radicalism opposes any attempt to unite the working class against capitalism in a revolutionary struggle by ignoring the roots of oppression in a capitalist society, which is based on class and advancing the sectoral interests of Black separatism to the detriment of the united class struggle. This action of the Black community has not only played into the hands of the ruling class of respective countries but has played the ruling class game and acted out the script of divisiveness from its playbook of racism as an ideology. This action is a clear justification of the ideology of racism, whose end goal is to split the Global Workers Movement along the ethnic/racial line and unconsciously aid and abet the same western capitalism and imperialism they critiqued.

The real test of building a global movement against imperialism lies in forging solidarity with other oppressed people who are also the victims of global capital- 
ism and imperialism. Without the class struggle of the Black working people to overthrow capitalism in different local contexts and driving solidarity with other oppressed groups across the world, achieving Black independence would either be a utopia or a mirage.

Finally, the Black independence in Andrews's articulation is based on Black separatism, which is counter-productive to the global movement that seeks to overthrow imperialism. Andrews (2018: p. 92) posited that "many of the arguments against separatism are actually harmful to Black progress even within the system". The danger of this position is that Black separatism is not fundamentally different from White segregationism, utilized by the American ruling class to promote division and disunity between the Whites and Blacks in the United States. This proposal about Black separatism further enables the ruling class to perpetuate racism (vis-à-vis racialisation) rather than bring people together to eradicate racism. In this sense, the Black separatists play the ruling class game by entrenching racism rather than challenging it.

The positions of Black radicalism on the future vision on racism hinges on its theoretical blind alley, which relied on the primacy of race over class in the understanding of racism in western society. This theoretical blind alley makes most of its solution to be illusory, utopia and unrealistic. My response to Walton on Black radicalism is what I had hoped that Cole could have undertaken in his initial response. Nevertheless, my position in this paper constitutes a significant fulcrum of a Marxist response to Walton's suggestion, using class analysis to deepen the understanding of racialization and racism in contemporary society.

\section{Conclusion}

This paper has offered a response to Sean Walton's suggestion that Marxism should not dismiss the CRT concept of White Supremacy. The paper has outlined why Marxists reject the notion of White Supremacy, using racism as an ideology to expand on the Marxist conception of racialization. The primacy of race over class in the CRT concept of White Supremacy has led to this Marxist rejection and represents a tunnelled manner of understanding racism in western society.

Through the ideology of racism, the western ruling class had used racialization as the basis of apportioning opportunities, privileges and benefits to White people over other racial groups, not because of their benevolence, generosity, and magnanimity but to segregate the Whites from the Blacks and other ethnic minorities and extend the culture of division that capitalism has represented for decades. It was clandestinely undertaken in a non-violence fashion as a ploy to prevent the unity of the people of different ethnic persuasions along the class line that could challenge the ruling class as a class for the failure and crisis of capitalism they superintended. Furthermore, the antics of the ruling class and its representatives in government/state institutions is intended to sustain people's fear and demoralization, blame others (especially foreigners, immigrants, refu- 
gees), and distract public attention by pitching one racial group against another. It uses the politics of racism and other tactics to create a cultural war artificially (e.g., between the current woke and anti-woke in the U.K.) to perpetuate disunity and division and prevent capitalism from being challenged and questioned.

The prioritization of the race question over the class issue central to the CRT and Black radical traditions has enabled the capitalist ruling class to continue the distraction through its politics of racism to prevent scrutiny of its role in maintaining racism. It is my considered opinion in this paper that abandoning the race issue and replacing it with the class question in the CRT and Black radicalism paradigms would enable us to strip racism naked. We would understand how the politics and tactics of the western ruling class have been instrumental in maintaining racism for too long without being challenged or facing formidable opposition. My position here on the discourse of racism and racialization is not intended to undermine the anti-racism campaign by creating division between CRT and Black radicalism and Marxism in terms of collaborating to fight and eradicate racism, but to articulate a new approach of strengthening the anti-racism movement and challenge the endemic episodes of racism in contemporary western societies.

In conclusion, I am proposing a class analysis of racialization that rejects incorporating the concept of White Supremacy into Marxist parlance on racism, as suggested by Sean Walton. It is my sincere hope that these debates continue in the intellectual and constructive spirit in which they are intended, and in doing so, we move to a useful analytical framework that could be utilized as practical templates and programmes of action to fight and end racism in social life.

\section{Conflicts of Interest}

The author declares no conflicts of interest regarding the publication of this paper.

\section{References}

Akbari, S. C. (2009). Idols in the East: European Representations of Islam and the Orient, 1100-1450. Cornell University Press.

Althusser, L. (1971). Ideology and Ideological State Apparatus. In Lenin and Philosophy and Other Essays (pp. 127-186). New Left Books.

Andrews, K. (2016). The Psychosis of Whiteness: The Celluloid Hallucinations of 'Amazing Grace' and 'Belle'. Journal of Black Studies, 47, 435-453. https://doi.org/10.1177/0021934716638802

Andrews, K. (2018). Back to Black: Retelling Black Radicalism for the 21st Century. Zed Books. https://doi.org/10.5040/9781350218574

Bale, A. (2006). The Jew in the Medieval Book: English Anti-Semitisms 1350-1500. Cambridge University Press.

Banton, M. (1991). The Race Relations Problematic. British Journal of Sociology, 42, 115-130.

Banton, M. (2005). Historical and Contemporary Modes of Racialisation. In K. Murji, \& J. 
Solomos (Eds.), Racialisation: Studies in Theory and Practice (pp. 51-68). Oxford University Press.

Biller, P. (1992). Views of Jews from Paris around 1300: Christian or 'Scientific'?" Studies in Church History, 29, 187-207. https://doi.org/10.1017/S0424208400011293

Carter, B., Harris, C., \& Joshi, S. (1987). The 1951-55 Conservative Government and the Racialisation of Black Immigration. Immigrants \& Minorities, 6, 335-347. https://doi.org/10.1080/02619288.1987.9974665

Cohen, P. N. (2001). Race, Class, and Labour Markets: The White Working Class and Racial Composition of U.S. Metropolitan Areas. Social Science Research, 30, 146-169. https://doi.org/10.1006/ssre.2000.0693

Cole, M. (2009a). Critical Race Theory Comes to the UK: A Marxist Response. Ethnicities, 9, 246-284. https://doi.org/10.1177/1468796809103462

Cole, M. (2009b). The Colour-Line and the Class Struggle: A Marxist Response to Critical Race Theory in Education as It Arrives in the United Kingdom. Power \& Education, 1, 111-124. https://doi.org/10.2304/power.2009.1.1.111

Cole, M. (2009c). On 'White Supremacy' and Caricaturing, Misrepresenting and Dismissing Marx and Marxism: A Response to David Gillborn's Who's Afraid of Critical Race Theory in Education. Journal for Critical Education Policy Studies, 7, 29-49.

Cole, M. (2009d). A Response to Charles Mills. Ethnicities, 9, 281-284. https://doi.org/10.1177/14687968090090020503

Cole, M. (2016). Racism: A Critical Analysis. Pluto Press.

Cole, M. (2020). A Marxist Critique of Sean Walton's Defence of the Critical Race Theory Concept of "White Supremacy" as Explaining All Forms of Racism, and Some Comments on Critical Race Theory, Black Radical and Socialist Futures. Power and Education, 12, 95-109. https://doi.org/10.1177/1757743819871318

Cole, M., \& Maisuria, A. (2010). Racism and Islamophobia in Post 7/7 Britain: Critical Race Theory, (Xeno-)Racialization, Empire and Education: A Marxist analysis. In D. Kelsh, D. Hill, \& S. Macrine (Eds.), Class in Education: Knowledge, Pedagogy, Subjectivity (pp. 108-127). Routledge.

Cox, O. C. (1959). Caste, Class and Race: A Study in Social Dynamics. Monthly Review Press.

Gillborn, D. (2016). Softly, Softly: Genetics, Intelligence and the Hidden Racism of the New Geneism. Journal of Educational Policy, 31, 365-388. https://doi.org/10.1080/02680939.2016.1139189

Gillborn, D. (2018). Heads I Win, Tails You Lose: Anti-Black Racism as Fluid, Relentless, Individual and Systematic. Peabody Journal of Education, 93, 66-77.

https://doi.org/10.1080/0161956X.2017.1403178

Glassman, J. (2006). Primitive Accumulation, Accumulation by Dispossession, Accumulation by 'Extra-Economic' Means. Progress in Human Geography, 30, 608-625. https://doi.org/10.1177/0309132506070172

Heng, G. (2003). Empire of Magic: Medieval Romance and the Politics of Cultural Fantasy. Columbia University Press.

Heng, G. (2018). The Invention of Race in the European Middle Ages. Cambridge University Press. https://doi.org/10.1017/9781108381710

Hill, D. (2020). Culturalist and Materialist Explanations of Class and "Race": Critical Race Theory, Equivalence/Parallelist Theory, and Marxist Theory. Cultural Logic: An Electronic Journal of Marxist Theory and Practice. http://www.ojs.library.ubc.ca

Khan, O., \& Shaheen, F. (2017). Introduction: Analysing and Responding to Racial and 
Class Inequalities. In O. Khan, \& F. Shaheen (Eds.), Minority Report: Race and Class in Post-Brexit Britain (pp. 4-7). Runnymede Trust.

Li, Y. (2017). Persisting Disadvantages: Barriers to Ethnic Social Mobility in the UK. In O. Khan, \& F. Shaheen (Eds.), Minority Report: Race and Class in Post-Brexit Britain (pp. 7-10). Runnymede Trust.

Li, Y., \& Heath, A. (2008). Ethnic Minority Men in the British Labour Market (1972-2005). International Journal of Sociology and Social Policy, 28, 231-244. https://doi.org/10.1108/01443330810881277

Marx, K., \& Engel, F. (2014). Communist Manifesto. Liberation Publication.

McKay, J. (2008). The Passage of the 1962 Commonwealth Immigrants Act, a Case-Study of Backbench Power. Observatoire de la Societe Britannique, 6, 89-108.

Miles, R \& Brown, M. (2003). Racism (2nd ed.). Routledge. https://doi.org/10.4324/9780203633663

Miles, R. (1982). Racism and Migrant Labour. Routledge and Kegan Paul.

Miles, R. (1989). Racism. Routledge.

Miles, R. (1993). Racism after “Race Relation”. Routledge.

Mills, C. W (2003). From Class to Race. Essays in White Marxism and Black Radicalism. Rowman \& Littlefield.

Mills, C. W. (1997). The Racial Contract. Cornell University Press.

Mills, C. W. (2009). Critical Race Theory: A Reply to Mike Cole. Ethnicities, 9, 270-281. https://doi.org/10.1177/14687968090090020502

Montagu, A. (1972). Statement on Race. Oxford University Press.

Patton, P. (2015). Envisioning Others: Race, Colour, and the Visual in Iberia and Latin America. Brill.

Rattansi, A. (2005). The Uses of Racialisation: The Time-Spaces and Subject-Objects of the Raced Body. In K. Murji, \& J. Solomos, (Eds.), Racialisation: Studies in Theory and Practice (pp. 271-301). Oxford University Press.

Robinson, C. (1983). Black Marxism: The Making of the Black Radical Tradition. Zed Press.

Rodney, W. (1972). How Europe Underdeveloped Africa. Bogle-L'Ouverture Publications.

Shain, F. (2016). Succeeding against the Odds: Can Schools 'Compensate for Society'? Education 3-13, 44, 8-18. https://doi.org/10.1080/03004279.2015.1122318

Simpson, D., Loughran, S., Lumsden, E., Mazzocco, P., McDowall Clark, R., \& Winterbottom, C. (2017). "Seen but not heard”. Practitioners Work with Poverty and the Organising Out of Disadvantaged Children's Voices and Participation in the Early Years. European Early Childhood Education Research Journal, 25, 177-188. https://doi.org/10.1080/1350293X.2017.1288014

Stoler, A. L. (1997). Racial Histories and Their Regime of Truth. Political Power and Social Theory, 11, 183-206.

Strickland, D. H. (2003). Saracens, Demons, and Jews: Making Monsters in Medieval Art. Princeton University Press.

Tolan, J. V. (2002). Saracens: Islam in the Medieval European Imagination. Columbia University Press.

Trachtenberg, J. (1943). The Devil and the Jews: The Medieval Conception of the Jew and Its Relation to Modern Antisemitism. Yale University Press. 
Walton, S. (2020). Why the Critical Race Theory Concept of 'White Supremacy' Should Not Be Dismissed by Neo-Marxists: Lessons from Contemporary Black Radicalism. Power and Education, 12, 78-94. https://doi.org/10.1177/1757743819871316

Webster, Y. O. (1993). The Racialisation of America. St Martins Press.

Women's Budget Group (2016). The Impact on Women of the 2016 Budget: Women Paying for the Chancellor's Tax Cuts.

http://wbg.org.uk/news/women-paying-chancellors-tax-cuts/

Ziegler, J. (2009). Physiognomy, Science, and Proto-Racism 1200-1500. In M. Eliav-Feldon, B. Isaac, \& J. Ziegler (Eds.), The Origins of Racism in the West (pp. 181-199). Cambridge University Press. 